\title{
DISRUPTION OF BEDROCK BY THE GROWTH AND COLLAPSE OF IGE LENSES
}

\author{
By Gordon Thom \\ (Department of Geography, University of Aberdeen, Aberdeen AB9 $2 \mathrm{UF}$, Scotland)
}

\begin{abstract}
Arstract. Hummocks and hollows were found developed in bedrock in the South Shetland Islands, Antarctica. Excavation revealed an ice lens $60 \mathrm{~cm}$ thick beneath a hummock. A cycle for the formation of the hummocks and hollows by the growth and collapse of ice lenses is suggested.

RÉsumÉ. Rupture du lit rocheux par la croissance et l'effondrement de lentilles de glace. On a trouvé que des protubérances et des creux s'étaient développés dans le lit rocheux des South Shetland Islands en Antarctique. Un forage a révélé une lentille de glace de $60 \mathrm{~cm}$ d'épaisseur sous une protubérance. Un cycle pour la formation de protubérances et de creux par la croissance et l'effondrement de lentilles de glace est suggéré.

Zusammenfassung. Zertrümmerung des Felsuntergrundes durch Wachsen und Zusammenbrechen von Eislinsen. Im Felsuntergrund der South Shetland Islands, Antarktika, wurde die Bildung von Buckeln und Hohlräumen festgestellt. Eine Grabung förderte eine Eislinse von $60 \mathrm{~cm}$ Dicke unter einem Buckel zutage. Ein Zyklus für die Bildung der Buckel und Hohlräume infolge des Wachsens und Zusammenbrechens von Eislinsen wird vorgeschlagen.
\end{abstract}

\section{INTRODUCTION}

The purpose of this note is to draw attention to the disruption of bedrock in a periglacial environment by a process which does not appear to have been reported previously at this scale. During the course of field work carried out in the austral summer of $1975^{-76}$ in the South Shetland Islands (Figs I and 2), it was noted that there were associations of hummocks and hollows developed on the surface of the lapillite-tuff bedrock of Byers Peninsula, Livingston Island (lat. $62^{\circ} 4 \mathrm{o}^{\prime} \mathrm{S}$., long. $6 \mathrm{I}^{\circ} \mathrm{oo}^{\prime} \mathrm{W}$.). The hummocks are in some respects similar to pingos incorporating bedrock (Müller, I959) but they are smaller and consist entirely of bedrock. Pingo collapse produces a mound whereas the end product of the cycle of growth and decay of the hummocks described here is a hollow.

\section{FORM MORPHOLOGY AND LITHOLOGY}

The hummocks and hollows were of similar sizes, being approximately $3 \mathrm{~m}$ in length, $2.5 \mathrm{~m}$ in depth and with a relief amplitude of $0.3 \mathrm{~m}$ (Table I). The surface of each hummock had a crack running parallel to the long axis of the form and sometimes another at rightangles to it (Fig. 3). The ground surface was covered by a layer of randomly arranged local bedrock clasts and was underlain by a layer of fines $2-6 \mathrm{~cm}$ in depth. Beneath this was fractured bedrock (Fig. 4). Excavation of a hummock revealed an ice lens at $0.45-0.6 \mathrm{~m}$ below the surface, with a maximum thickness of $0.6 \mathrm{~m}$. The ice was largely debris-free except for its margins where some bedrock fragments were in part incorporated. Vertically aligned

TABle I. Sizes of HUMmocks AND hollows

Length, m

Width, $m$

Height/depth, m

Slope angle on side, deg

Crack width, $\mathrm{m}$

Crack depth, $\mathrm{m}$

$\begin{array}{ccc} & \text { Hummocks } & \\ \text { Mean } & \text { Maximum } & \begin{array}{c}\text { Standard } \\ \text { deviation }\end{array} \\ 3.2 & 4.1 & 0.84 \\ 2.5 & 3.6 & 0.91 \\ 0.33 & 0.57 & 0.15 \\ \text { 13 } & 24 & 4.8 \\ \text { 0.1 I } & \text { 0.18 } & 0.03 \\ 0.31 & 0.47 & 0.09 \\ & & \end{array}$

\begin{tabular}{ccc}
\multicolumn{3}{c}{ Hollows } \\
Mean & Maximum & $\begin{array}{c}\text { Standard } \\
\text { deviation }\end{array}$ \\
2.9 & 4.6 & 0.97 \\
2.5 & 4.5 & 1.04 \\
0.28 & 0.35 & 0.06 \\
I I & 1 7 & 3.6 \\
- & - & - \\
- & - & -
\end{tabular}



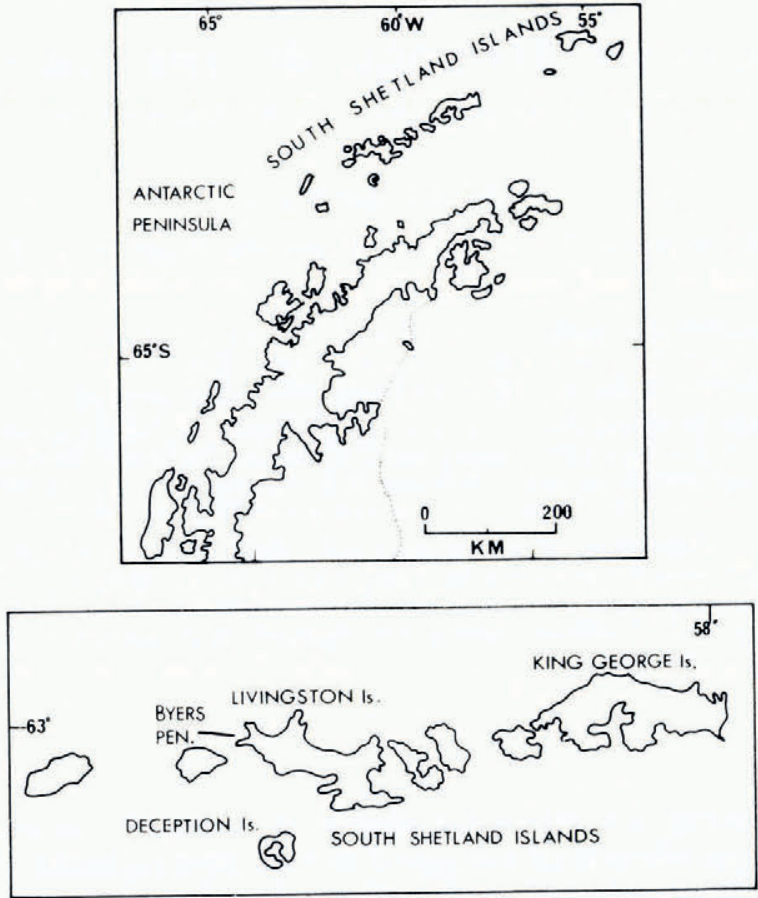

Fig. I. The Antarctic Peninsula and the South Shetland Islands.

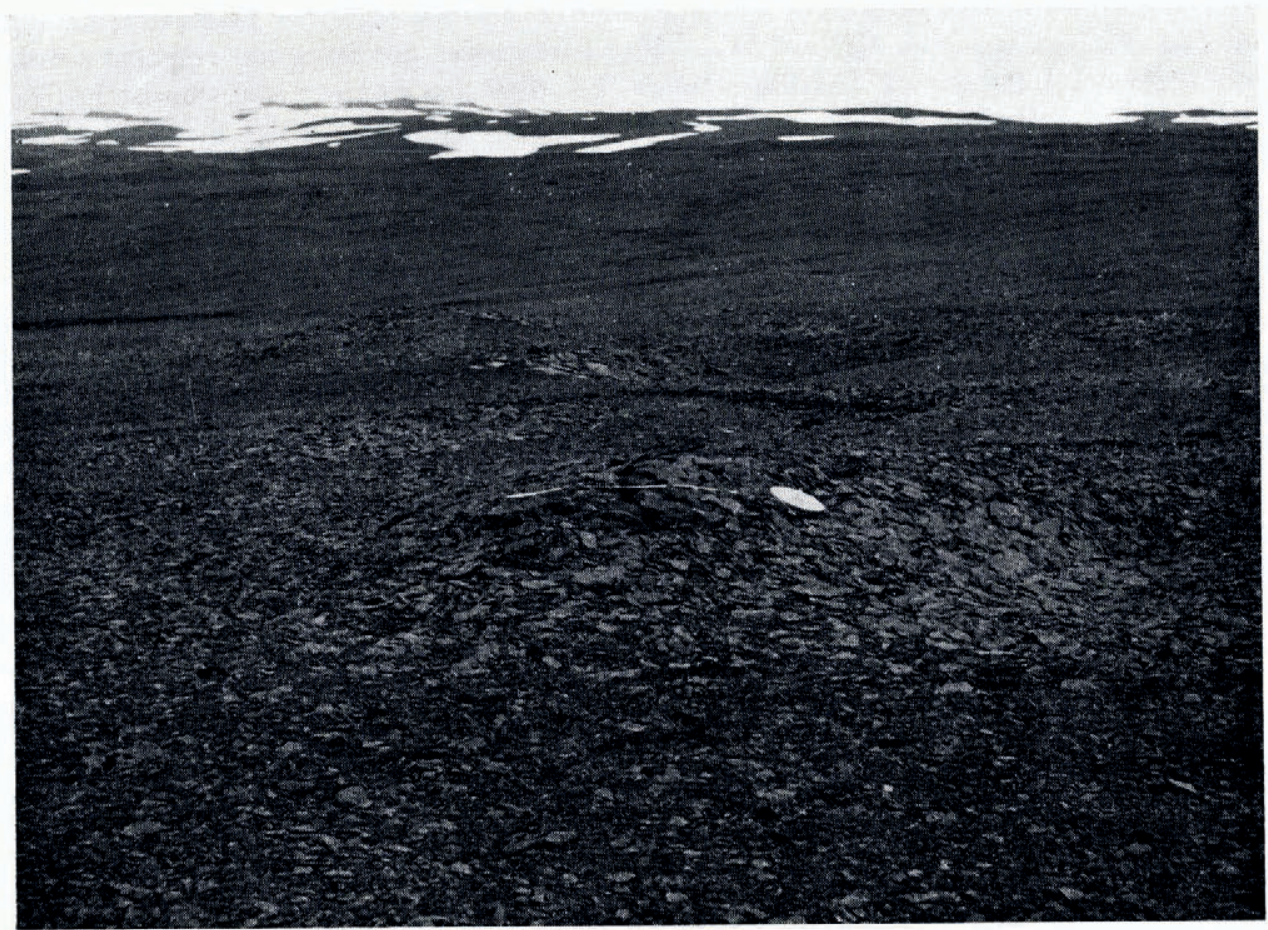

Fig. 2. A typical association of hummocks and hollows. I $m$ of tape visible. 


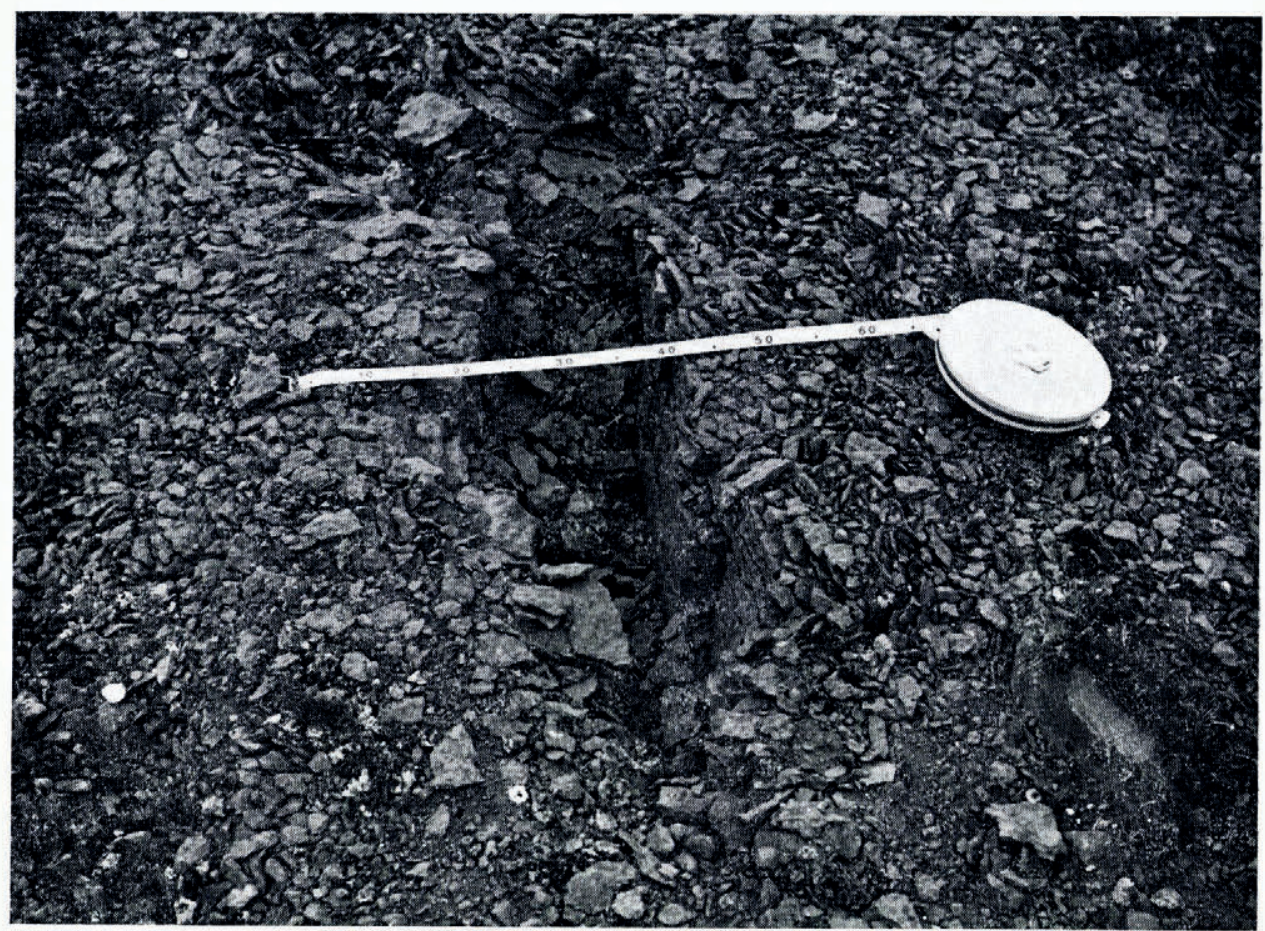

Fig. 3. One of the best-developed surface cracks.

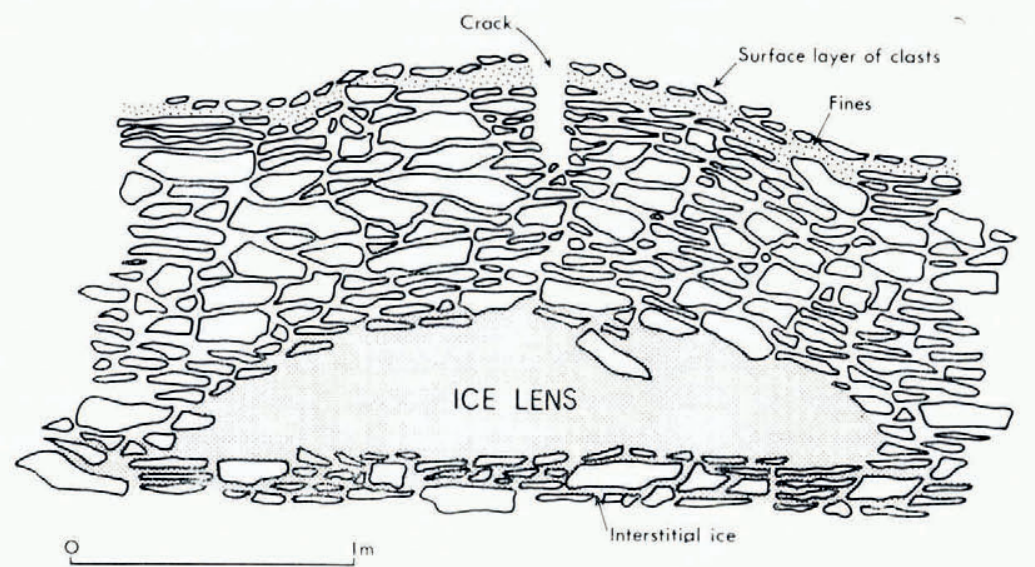

Fig. 4. Section through a hummock, based on photographs and field sketches.

lines of bubbles suggest that it is a lens of segregation origin (Washburn, I973). Beneath the lens the bedrock was cemented by interstitial ice. The bedrock is a lapillite-tuff with clasts of pumice which are typically between $\mathrm{I}$ and $\mathrm{I} 0 \mathrm{~mm}$ in diameter, though they may be up to $3 \mathrm{~cm}$ in size (personal communication from R. E. S. Davies, I977). The tuff is very friable and breaks along horizontal or sub-horizontal planes to produce platy clasts about ${ }^{10-}-{ }_{5} \mathrm{~cm}$ in length, with a maximum of approximately $45 \mathrm{~cm}$. 


\section{ENVIRONMENT}

The climate of the South Shetland Islands is typical of the maritime Antarctic. Meteorological data are not available for Livingston Island but Pepper (I954) has given data for Admiralty Bay, King George Island (lat. $62^{\circ} \mathrm{Io}^{\prime}$ S., long. $58^{\circ} 30^{\prime}$ W.) and Whalers Bay, Deception Island (lat. $63^{\circ} \mathrm{oo}^{\prime} \mathrm{S}$., long. $60^{\circ} 3 \mathrm{o}^{\prime} \mathrm{W}$.) (Table II). For most years the mean daily temperature is above freezing from December to March, so that melting of frozen ground is possible during this period. Permafrost was found at all sites investigated during the course of field work on Livingston Island. In January and February, when the work was carried out, the depth of the active layer at low altitudes (less than $30 \mathrm{~m}$ ) was between 0.3 and $0.7 \mathrm{~m}$, depending on materials.

Table II. Climatic statistics for Whalers Bay and Admiralty Bay

$\begin{array}{lcc} & \begin{array}{c}\text { Whalers Bay } \\ { }^{\circ} \mathrm{C}\end{array} & \begin{array}{c}\text { Admiralty Bay } \\ { }^{\circ} \mathrm{C}\end{array} \\ \text { Mean annual temperature } & -2.8 & -2.7 \\ \text { Mean daily temperature, January } & +\mathrm{r} .4 & +\mathrm{r} .3 \\ \text { Mean daily maximum, January } & +\mathrm{I} .7 & +3.3 \\ \text { Mean daily temperature, July } & -8.2 & -8.0 \\ \text { Mean daily minimum, July } & -\mathrm{I} .5 & -\mathrm{I} .4 .4\end{array}$

\section{INTERPRETATION}

It would seem that the growth of the ice lens is causing the hummock and it is suggested that the hollows result from the collapse of the hummocks following the melting of the ice. A cycle of growth and decay of ice lenses is suggested as follows:

I. An ice lens is initiated at a point in the bedrock and begins to grow, heaving up the bedrock which cracks vertically to accommodate the expansion and deformation.

2. As the ice lens grows, the sides of the hummock steepen, enhancing mass wasting and resulting in the removal of material from the hummock.

3. During the winters the lens increases in size until a threshold is reached when the widening of the crack alters the thermal conductivity of the system to such an extent that the lens is susceptible to melting in subsequent summers.

4. With the melting of the lens the bedrock collapses and, because of the removal of material from the system, a hollow is produced.

No climatic change is necessary for the cyclical growth and collapse of ice lenses in this model so that the development of hummocks and hollows is possible under the present climate of Byers Peninsula. Lapillite is the dominant bedrock type of eastern Byers Peninsula, comprising $70 \%$ of the succession, so that this process is at least locally important and may be active in other periglacial environments with a suitable lithology.

\section{Acknowledgements}

The research was part of a geomorphological programme in the Antarctic supported by the Natural Environment Research Council and the British Antarctic Survey, with study facilities at the Department of Geography, University of Aberdeen. Thanks are due to R. V. Birnie, J. D. Hansom, and Dr J. E. Gordon for assistance in the field, to Dr A. M. D. Gemmell and Dr D. E. Sugden for their comments during the preparation of the manuscript, and to R. E. S. Davies for identifying geological specimens.

\section{MS. received 31 August 1977 and in revised form 10 February 1978}




\section{REFERENGES}

Müller, F. 1959. Beobachtungen über Pingos. Detailuntersuchungen in Ostgrönland und in der kanadischen Arktis. Meddelelser om Grenland, Bd. I53, Nr. 3. [English translation: Canada. National Research Council. Technical Translation $1073,1963$.

Pepper, J. 1954. The meteorology of the Falkland Islands and Dependencies, 1944-5o. London, Falkland Islands and Dependencies Meteorological Service.

Washburn, A. L. 1973. Periglacial processes and environments. London, Edward Arnold. 